\begin{tabular}{|c|c|c|}
\hline Beitr. Ent. & Keltern & ISSN 0005 - 805X \\
\hline $\mathbf{5 4}(2004) 1$ & S. 31-35 & 28.05 .2004 \\
\hline
\end{tabular}

\title{
Revisional notes on Sericini: The taxonomic status of the "Neotropical" genus Rhynchosymmela FREY, 1974
}

\section{(Coleoptera, Scarabaeidae)}

With 2 frgures

\author{
DIRK AHRENS
}

\section{Summary}

Based on an examination of the holotype, Rbynchosymmela pallida FREY, 1974 is recognized as a junior synonym of Hemiserica nasuta BRENSKE, 1894. The type locality of Rbynchosymmela pallida FREY is suspected to be erroneous. Important morphological characters of the holotype of Rbyncbosymmela pallida FREY are figured and the distribution of Hemiserica, as well as that of Hemiserica nasuta, is mapped.

\section{Zusammenfassung}

Basierend auf das Studium des Holotypus von Rhynchosymmela pallida FREY, 1974 wurde festgestellt, dass das Taxon ein jüngeres Synonym von Hemiserica nasuta BRENSKE, 1894 ist. Es wird angenommen, dass der Locus typicus von Rhyncbosymmela pallida FREY einer Fundortverwechslung unterlegen haben muss. Wichtige morphologische Merkmale des Holotypus von Rhynchosymmela pallida FREY werden abgebildet, und die geographische Verbreitung von Hemiserica wie auch von Hemiserica nasuta dargestellt.

\section{Key words}

Coleoptera, Scarabaeidae, Hemiserica, Rhynchosymmela, erroneous type locality, new synonymy, India, Panama

The Sericini is a large tribe within the Scarabaeidae and includes more than 3000 species. Little is known about the species biology. Lacking in Notogea, the tribe is best represented in tropical region. Preliminary investigations on phylogeny of the tribe have shown that Paleotropical and Holarctic species form a monophyletic group. This monophyletic assemblage is regarded as the sister group of a clade of Neotropic taxa, including the genera Astaena ERICHSON, 1847 and Symmela ERICHSON, 1835 (AHRENS 2002).

The genus Rbynchosymmela, which was erected by FREY (1974) for a single species, Rhynchosymmela pallida FREY, 1974, from Panama, has been regarded as a representative of the Neotropical fauna (EVANS 2001, 2003). During a recent visit to the Hungarian Natural 
History Museum in Budapest, I had the opportunity to examine the holotype of the species under question. It soon became apparent that Rhynchosymmela pallida FREY, 1974, was synonymous with Hemiserica nasuta BRENSKE, 1894, described from Northern India. Consequently the genus Rhynchosymmela must be regarded as a junior synonym of Hemiserica BRENSKE, 1894.

\section{Hemiserica BRENSKE, 1894}

Hemiserica BRENSKE, 1894: 11 (type species by monotypy: Hemiserica nasuta BRENSKE, 1894).

Rbynchosymmela FREY, 1974: 120 (type species by monotypy: Rbynchosymmela pallida FREY, 1974), syn. $\mathbf{n}$.

The genus Hemiserica was erected by BRENSKE (1894) for a single species Hemiserica nasuta BRENSKE, 1894, from Northern India. The genus was based on the characteristical shape of labroclypeus, which is narrowed before the strongly reflexed anterior border. Later taxa added to the genus include: Hemiserica armipes ARROW, 1945, H. bilobata ARROW, 1945, H. mayarami KHAN \& GHAI, 1980, H. pallida ARROW, 1945, and H. trilobata KHAN \& GHAI, 1980. All these species occurr exclusively on the Indian subcontinent (Fig. 2) and are only rarely found in collections. The species occurring in the Himalayas have been revised by AHRENS (in press a).

\section{Hemiserica nasuta BRENSKE, 1894}

Hemiserica nasuta BRENSKE, 1894: 57, 87; BRENSKE 1897: 385, BRENSKE 1902a: Tf. 1.

Hemiserica clypeata BRENSKE, 1894: 11 [nomen nudum].

Hemiserica pallida ARROW, 1945: 119 (locus typicus: N.W. India).

Rhyncbosymmela pallida FREY, 1974: 120, syn. n.

Locus typicus. Saidabad Kashmir [Northern India].

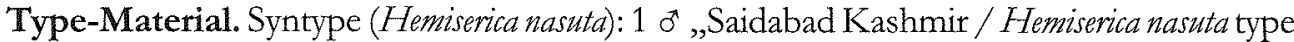
Brenske / Typus" (Zoological Museum of Humboldt University, Berlin). Holotype (Rhynchosymmela pallida): o" "Vandom 1887 Panama / Type o" Rbynchosymmela pallida G. Frey 1972 / Holotypus Rhynchosim. n.g.pallida G. Frey" (Hungarian Natural History Museum, Budapest). Paratypes (Rhynchosymmela pallida): 1 \% "Vandom 1887 Panama / Paratype o Rhyncbosymmela pallida G. Frey 1972 / Paratypus Rhynchosim. n.g.pallida G. Frey" (Hungarian Natural History Museum, Budapest).

Remarks. AHRENS (in press a) redescribed Hemiserica nasuta and discussed its taxonomy and synonymy. The holotype of Rbynchosymmela pallida and the syntype of Hemiserica nasuta are virtually identical in shape of parameres (Fig. 1A-C) and in most external diagnostic features (Fig. 1D-E), consequently I consider them to be synonymous. Labels on holotype: Fig. 1F.

Aedeagus. AHREns (in press a), Aedeagus of Holotype of Rbynchosymmela pallida: Fig. 1A-C. 


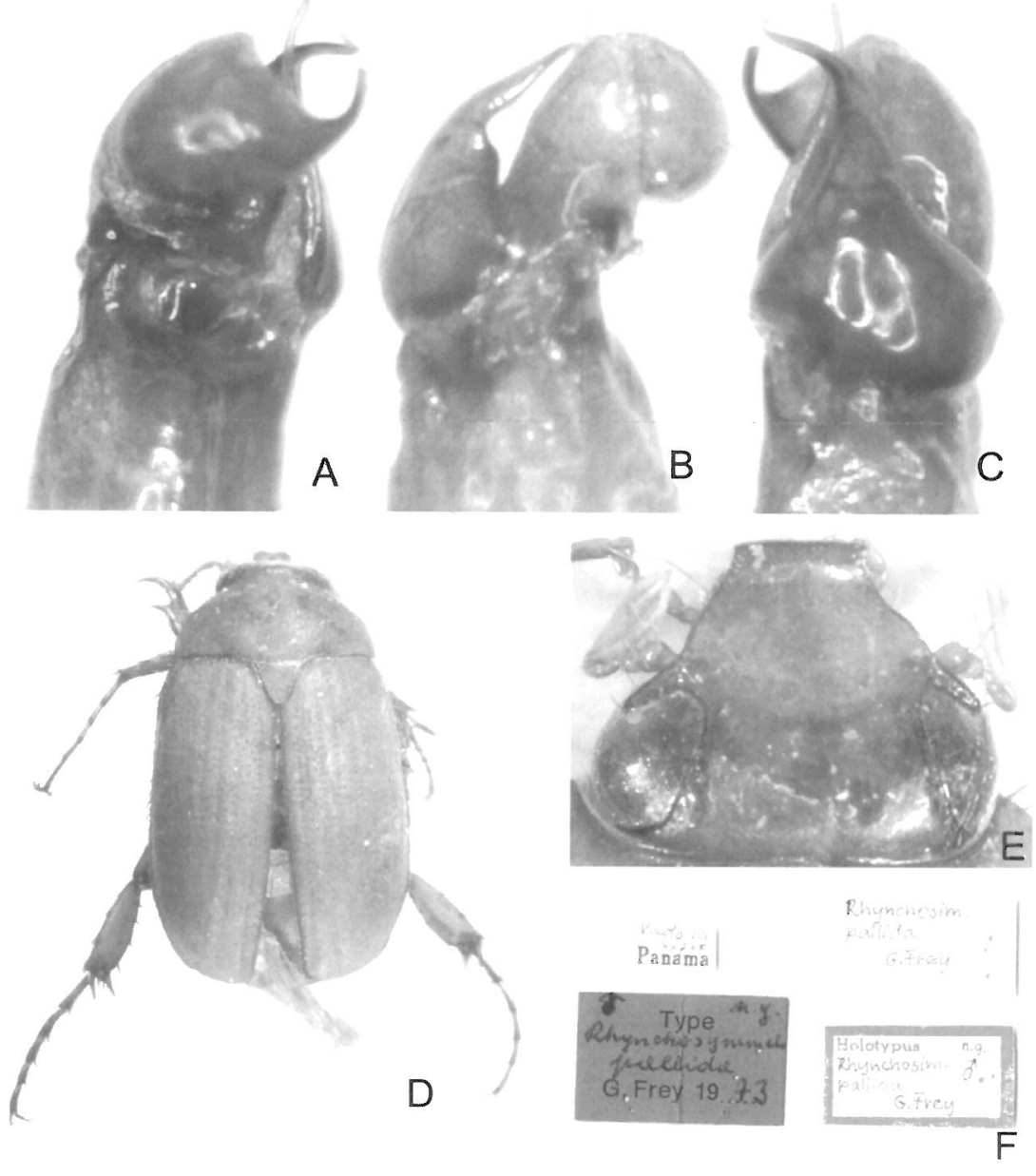

Fig. 1: Holotype of Rhynchosymmela pallida: A-C: Male genitalia, parameres, A: lateral view, left side, B: dorsal view, C: lateral view, right side; $\mathbb{D}$ : Habitus; E: Head; F: Labels.

Distribution. The species is restricted to Northern India (Fig. 2).

Discussion. Instances of the importation of Sericini species have been reported several times (AHRENS 2000a, 2003a, AHRENS \& KLESS 2001). Generally speaking, imported species must have survived in their new locality for an extended period of time, otherwise the probability of detecting such an importation would be rather low. Conversely, detection of a very short-term survival following importation, especially in regions were collecting activity is rare, would be nearly impossible. Consequently, in instances where species are found well outside their normal range and have not subsequently been reported from the new area, the accuracy of the locality labels comes into question. Cases such as this, erroneous label data, are rather frequently encountered among the Sericini (AHRENS 2000b, 2003b, AHRENS in press a, b). Since most specialists work regionally, this problem was often not recognized and has led to synonymies of both species and generic names. 


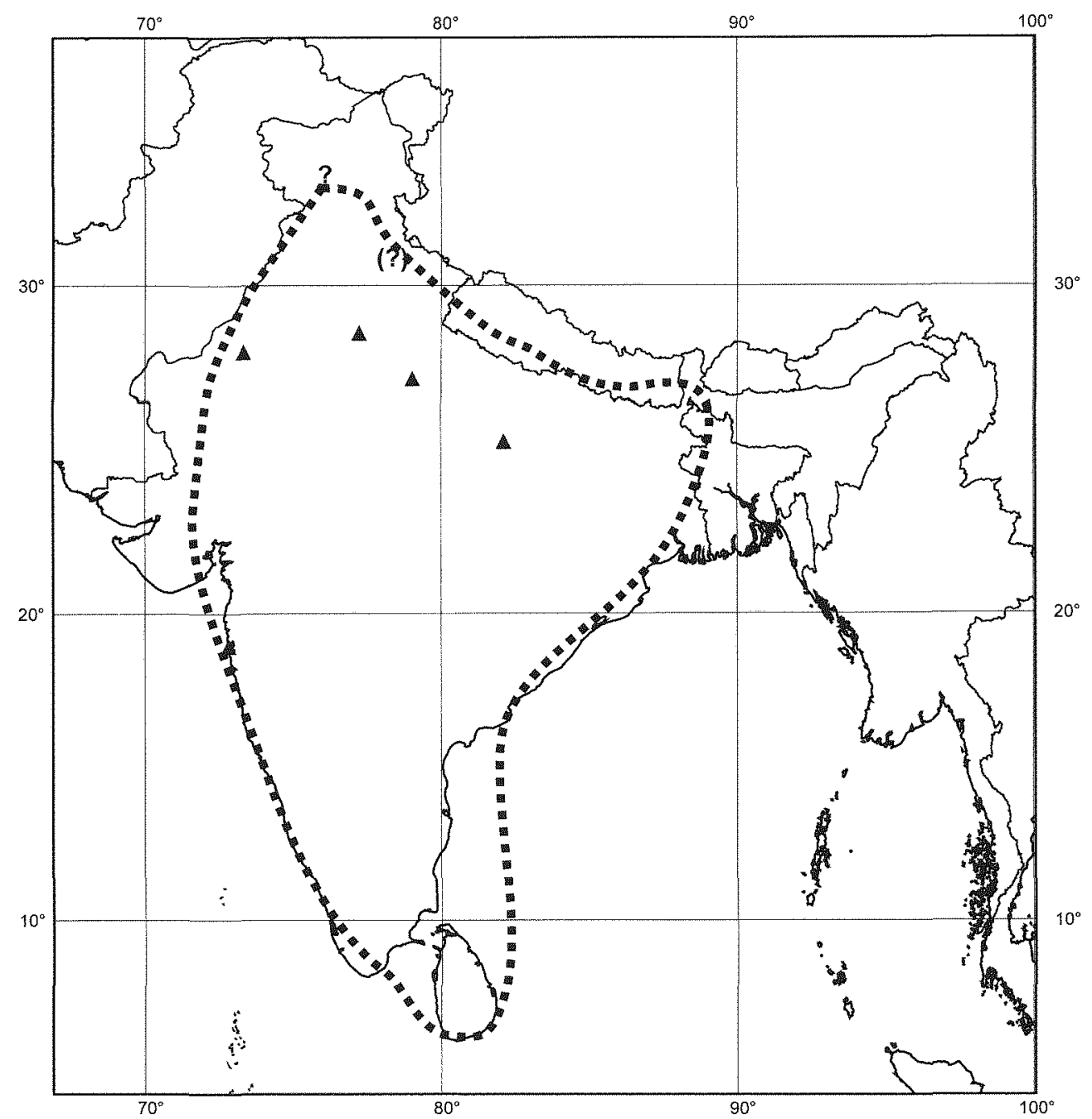

Fig. 2: Distribution of the genus Hemiserica BRENSKE, 1894 (dotted line) and of Hemiserica nasuta BRENSKE, 1894 (triangle, "?"- not precisely located tecords).

All species of Hemiserica are rather restricted geographically, the representatives occurring on Indian subcontinent only. Although little is known about the Sericine fauna of Panama, the facts seems to favour the hypothesis that in case of Rhynchosymmela pallida, the specimens were erroneously labelled.

\section{Acknowledgements}

I am grateful to Otto Merkl (Hungarian Natural History Museum, Budapest) for the fiendly support during my visit at HNHM and for making specimens available to me for this study. This publication is part of a project supported by a DFG grant (GRK 503/2). I am very grateful to Paul Lago (Mississippi) for reviewing the manuscript. 


\section{References Cited}

Ahrens, D. 2000a: Serica kargei Petrovitz, 1967 aus der Türkei - ein neues Synonym von Autoserica castanea ARROW, 1913 (Colcoptera: Melolonthidae: Sericini). - Reichenbachia 33: 395-298.

AHRENS, D. 2000b: Neue Erkenntnisse zur Herkunft von Autoserica caifensis BRENSKE, 1897 (Insecta: Coleoptera: Melolonthidae). - Linzer Biologische Beiträge 32: 71-74.

AHRENS, D. 2002: Orogenesis and evolutionary radiation: patterns of sericid beetles (Coleoptera: Scarabaeidae) in the Himalayas. - International Symposium: Mesozoic-Cenozoic Bioevents: Possible links to impacts and other causes, Berlin, 21. - 23. November 2002: 51 .

AHRENS, D. 2003a: Maladera affinis (BLANCHARD) (Coleoptera, Scarabaeoidea, Sericini), an oriental faunal element in Malagasy tegion. - Deutsche Entomologische Zeitschrift 50: 133-142.

AHrens, D. 2003b: Zur Identität der aus Madagaskar beschriebenen_Autoserica stupida BRENSKE, 1900 (Coleoptera, Scarabaeidae, Sericini). - Beiträge zur Entomologie 53: 231-238.

Ahrens, D. in press a: Monographie der Sericini des Himalaya (Coleoptera, Scarabaeidae). - Folia Heyrovskyana, Supplement 11.

AHRENS, D. in press b: On occurrence and synonymy of Maladera rubida (MOSER, 1915) comb. n. (Coleoptera, Scarabaeidae, Sericini). - Journal of East African Natural History.

AHrENS, D. \& KLESS, J. 2001: Eine importierte nordametikanische Serica-Art (Coleoptera, Scarabaeoidea, Sericini) in Baden-Württemberg. - Entomologische Zeitschrift 111: 153-155.

Arrow, G. J. 1945: On the Melolonthine Beetles of the Genus Hemiserica including a few new Species. Annals and Magazine of Natural History, Series 11, 12: 117-121.

BRENSKE, E. 1894: Die Melolonthiden der palaearktischen und orientalischen Region im Königlichen naturhistorischen Museum zu Brüssel. Beschreibung neuer Atten und Bemerkung zu bekannten. Memoire de la Société Entomologique de Belgique 2: 3-87.

ERICHSON, W. F. 1835: Neue Südamerikanische Käfergattungen aus der Familie des Blätterhörner. - Archiv für Naturgeschichte 1: 256-270.

ERICHSON, W. F. 1847: Conspectus Insectorum Coleoptetorum quae in Republica Peruana observata sunt. - Archiv für Naturgeschichte 13: 67-185.

Evans, A.V. 2001: Catalog of the New World Melolonthinae (Coleoptera: Scarabaeoidea, Scarabaeidae). http://www.mus.un1.edu/research/entomology/Guide/Melolonthinae/MelolonthinaeO.htm

EVANS, A.V. 2003: A checklist of the New World chafers (Coleoptera: Scarabaeidae: Melolonthinae). Zootaxa 211: $458 \mathrm{pp}$.

FrEY, G. 1974: Neue Melolonthiden von den Expeditionen des ungarischen Nationalmuseums in Budapest, gesammelt von den Herren Dr. S. Endrödi-Younga und Dr. J. Szunyoghy, sowie eine neue mittelamerikanische Gattung der Sericinae. - Entomologische Arbeiten aus dem Museum G. Frey 25: 109-120.

KHAN, K. M. \& GHAI, S. 1980: Notes on the genus Hemiserica BRENSKE with descriptions of two new species from India and key to species. - Bulletin of Entomology 21: 40-43.

\section{Anschrift des Verfassers:}

DIRK AHRENS

Deutsches Entomologisches Institut

im Zentrum für Agrarlandschafts- und

Landnutzungsforschung (ZALF)

Schickletstraße 5

D-16225 Eberswalde

Deutschland

e-mail: dahrens@zalf.de, ahrens.dirk_col@gmx.de 